\title{
Appendix Lipoma
}

National Cancer Institute

\section{Source}

National Cancer Institute. Appendix Lipoma. NCI Thesaurus. Code C43576.

A benign adipose tissue neoplasm involving the wall of the appendix. 